\title{
Práticas de Avaliação da Aprendizagem e sua Relação com a Formação Continuada de Professores no Cotidiano do Trabalho Escolar
}

\author{
SUZANA DOS SANTOS GOMES \\ Mestre em Educação pela FAE/UFMG. Professora nos Cursos de Licenciatura da \\ FAE/UFMG e nos Cursos de Graduação da PUC/MG \\ suzanasg@terra.com.br
}

\begin{abstract}
Resumo
Este texto apresenta alguns resultados obtidos em uma pesquisa que objetivou identificar a relação existente entre a implementação de práticas de avaliação formativa e a formação continuada dos professores no cotidiano do trabalho escolar. A pesquisa foi desenvolvida por meio de estudo de caso, de natureza qualitativa, tendo como fonte de dados as observações dos espaços-tempos coletivos dos professores, entrevistas e análises de documentos, em duas escolas de $3^{\circ}$ ciclo da educação fundamental. As análises estão fundamentadas em autores considerados referência nas pesquisas sobre formação de professores: Nóvoa $(1992,1995)$; Zeichner $(1990,1993,2000)$, Schön $(1992,2000)$ e outros. A análise dos dados revelou que as situações do cotidiano escolar oferecem contextos favoráveis à promoção de processos de formação continuada; produção de saberes, pelos professores, para compreensão e interpretação da prática; e, conseqüentemente, aperfeiçoamento do fazer docente de avaliação e intervenção pedagógica. Os resultados sugeriram, também, maior investimento nas ações de formação continuada nos espaçostempos do cotidiano escolar a fim de que propostas docentes alternativas se efetivem na prática escolar.

Palavras-chave: avaliação da aprendizagem, professores, formação continuada, saberes docentes.
\end{abstract}

\begin{abstract}
Resumen
El artículo presenta algunos resultados obtenidos en una investigación que buscó identificar la relación entre la implementación de prácticas de evaluación formativa con la formación continua de los profesores en la rutina del trabajo escolar. La investigación se realizó a través del método del caso, de naturaleza cualitativa, utilizando como fuente de datos, las observaciones de espacios-tiempos colectivos de los maestros, encuestas y estudios de documentación en dos escuelas del 3er. grado de Enseñanza Fundamental. Los análisis se fundamentan en autores que son considerados puntos de referencia en las investigaciones sobre formación de maestros: Nóvoa (1992, 1995), Zeichner (1990, 1993, 2000), Schön (1992, 2000) y otros. El estudio de los datos demostró que las situaciones de la rutina cotidiana escolar ofrecen situaciones favorables a la promoción de procesos de formación continua;
\end{abstract}


producción de conocimientos, por parte de los maestros, para la comprensión e interpretación de la práctica $\mathrm{y}$, consecuentemente, del perfeccionamiento del quehacer docente en la evaluación y en la intervención pedagógica. Los resultados sugirieron, también, una mayor inversión en las acciones de formación continua en los espaciostiempos de la rutina cotidiana escolar para que se efectúen las propuestas docentes alternativas en la práctica escolar.

Palabras-clave: evaluación de aprendizaje, maestros, formación continua, conocimientos docentes.

\begin{abstract}
This text presents some of the results arrived at in a research which aimed at identifying the relationship between the implementation of practices of formative assessment and their relationship with teachers' continuing in-service education. The research, carried out through quantitative case studies, observed the teachers' time-and-space relationship, interviewed them and also analysed documents of two elementary schools. Such analyses were based on works by such renowned authors as Nóvoa (1992, 1995), Zeichner (1990, 1993, $2000)$ and Schön $(1992,2000)$, among others. The analysis of the data revealed that the school environment offered positive contexts thus allowing for teachers to promote their continuing education, producing knowledge, as well as understanding and interpreting their practice and, consequently, improving both their assessment practice and pedagogical interventions. The results also suggest that greater investment in actions of continuing education in timeand-space sharing at school are needed so that teachers' alternative proposals can have an effective impact on school practice.
\end{abstract}

Key words: learning assessment, teachers, continuing education, teachers' knowledge. 


\section{INTRODUÇÃO}

Este texto discute as experiências de formação vivenciadas pelos professores no cotidiano do trabalho escolar e as influências que elas exercem na implementação de modelos alternativos de avaliação da aprendizagem, aqui denominada avaliação formativa. Apresenta e analisa fragmentos do cotidiano escolar de duas escolas municipais de $3^{\circ}$ ciclo do ensino fundamental em Belo Horizonte, bem-sucedidas, cujos professores, à época da pesquisa, estavam envolvidos na reorganização do ensino e na implementação da Escola Plural. Com esse procedimento, objetiva-se, a partir da aprendizagem profissional no cotidiano escolar, vislumbrar algumas perspectivas para a formação em serviço dos docentes. As análises estão fundamentadas em autores considerados referência nas pesquisas sobre formação de professores: Nóvoa (1992, 1995); Zeichner (1990, 1993, 2000); Schön (1992, 2000) e outros.

Neste trabalho, denomina-se formação em serviço ou formação continuada a formação não-acadêmica, realizada no dia-a-dia do trabalho docente e nos espaços-tempos do cotidiano dos professores nas escolas. Essa formação consiste em propostas voltadas para a qualificação do docente, tendo em vista as possibilidades de melhoria de sua prática pelo domínio de conhecimentos e de métodos de seu campo de trabalho. Esses conteúdos podem estar relacionados com a superação de problemas ou de lacunas na prática docente, ou podem promover a introdução de um novo repertório de conhecimentos, de natureza teórica ou prática, decorrentes da produção de novos saberes nas diferentes áreas do conhecimento. Enquanto no primeiro caso o objetivo principal é sanar diferentes tipos de demandas diagnosticadas na prática docente, no segundo é, sobretudo, atualizar o professor.

Trata-se de um estudo de caso de natureza qualitativa, realizado a partir da inserção do pesquisador na realidade escolar (Gomes, 2003). Utilizaram-se como procedimentos metodológicos: análise de documentos, entrevistas e observações dos professores nos espaços-tempos de formação (reuniões pedagógicas, seminários, encontros e outros). A coleta de dados foi realizada em 2002. As entrevistas com os professores ocorreram de agosto a outubro do mesmo ano. A análise dos documentos, que continham registros sobre a prática de avaliação e o processo de formação docente, transcorreu durante a coleta de dados. Essa análise evidenciou questões relevantes para este estudo.

Uma vez que meu objeto de estudo se referia à prática docente de avaliação dos professores, a observação incidiu sobre uma série de aspectos 
que revelaram, de forma explícita ou implícita, seus significados. No entanto, ao longo da pesquisa, não perdi de vista o caráter dinâmico da vida escolar. Nesse sentido, foram os processos que constituíram o cotidiano que me interessava captar. Por exemplo: como as pessoas se apropriavam de certos conceitos, por que lhes atribuíam certos sentidos, a forma como trabalhavam seus significados, como isso refletia na prática, etc. Desse modo, a escola como um todo foi o alvo da observação, mas como minha preocupação se centrava nas práticas de avaliação dos professores do $3^{\circ}$ ciclo alguns espaços receberam atenção particular: a sala de aula, a sala dos professores, as reuniões administrativo-pedagógicas, os conselhos de classe e outras instâncias em que a presença dos professores era constante.

Para garantir maior veracidade dos dados, as observações de campo foram registradas de forma descritiva. Os registros também incorporaram as reflexões e idéias que as observações suscitavam, assim como os temas e padrões que iam emergindo durante o trabalho. A observação participativa da sala de aula, dos conselhos de classe e dos espaços coletivos de interação dos professores foi muito importante na coleta de dados.

Meu objetivo com as questões propostas era mergulhar nas respostas dos professores tentando captar, mais detalhadamente, a prática docente de avaliação, detectando os significados essenciais dos processos vividos por eles. Os dados oriundos dessas entrevistas foram organizados cuidadosamente de acordo com o registro das falas dos entrevistados em sua totalidade. Fiz uma leitura preliminar das respostas dadas para uma visão geral; em seguida, fiz releituras para destacar as opiniões dos entrevistados e para selecionar os principais dados.

Vale ressaltar que as informações que obtive com as entrevistas apresentaram dados referentes à formação do professor, às experiências profissionais, à concepção de educação/ensino, ao aluno/professor, à avaliação, à prática pedagógica, e, também, os principais problemas enfrentados em sala de aula e a busca de alternativas. Esses elementos são considerados significativos em uma proposta de avaliação formativa.

A análise de documentos foi outro recurso que utilizei neste estudo. Considerei como documento os registros escritos, realizados pelos professores e pela coordenação pedagógica do $3^{\circ}$ ciclo, que pudessem ser usados como fonte de informação. Assim, foram analisados os documentos considerados mais importantes para a pesquisa: o projeto político pedagógico da escola, o projeto do $3^{\circ}$ ciclo, os instrumentos de avaliação e registros do Projeto Intervenção, as atas de conselhos de classes e as 
sínteses dos estudos realizados pelas escolas sobre avaliação formativa nos espaços-tempos de formação em serviço.

Considerou-se que o repensar da ação docente aconteceu em diversos espaços-tempos. Nesse sentido, mereceu destaque o espaço da formação no cotidiano do trabalho escolar. Ele se revelou como condição favorável à implementação da avaliação formativa e, conseqüentemente, ao ensino diferenciado.

Todavia, essa afirmação suscita algumas questões que serão respondidas neste trabalho: a qualidade da prática docente de avaliação relaciona-se com a formação continuada dos professores? Os espaçostempos coletivos dos professores interferem em sua forma de avaliar e ensinar?

Por fim, cabe assinalar que os resultados obtidos neste estudo podem contribuir para compreender as relações que ocorrem no cotidiano escolar entre professor-aluno e professor-professor, apontar as conseqüências dessas relações e dar pistas para a superação do fracasso escolar. Daí, a sugestão: acelerar a profissionalização e melhorar o nível de formação dos professores. Espera-se, ainda, que este estudo aponte elementos que ajudem a repensar a formação continuada dos professores; sinalize para os elaboradores e proponentes de políticas públicas a urgência na formulação de políticas de formação permanente, capazes de promover adequada atualização dos princípios teóricos e metodológicos, lembrando que os professores são aprendizes desses novos pressupostos inclusivos.

\section{OS PROFESSORES NOS ESPAÇOS-TEMPOS DE AVALIAÇÃO E FORMAÇÃO CONTINUADA}

A educação brasileira vem enfrentando vários problemas. Um deles diz respeito à formação de docentes, que tem sido um desafio para os pesquisadores e gestores de políticas públicas educacionais. Atuando nesse campo, Corrêa e Souza (2001) afirmam que a expansão do acesso à educação, principalmente ao ensino fundamental, provocou a ampliação das redes de ensino e, conseqüentemente, a demanda por melhores condições de trabalho do professor, o que inclui uma formação prévia e contínua adequada ao exercício profissional.

Nesse sentido, a identificação do tipo de formação dos professores, nesta pesquisa baseou-se no projeto Escola Plural. Constatou-se que orientado pelo eixo nova identidade da escola, nova identidade do seu profissional, pretende-se continuar construindo, juntamente com essa nova 
escola, um novo professor, um profissional com nova identidade, novos saberes e novas habilidades, mais plural, mais politécnico e que tenha acesso a um rico processo de formação em serviço. E isso só ocorrerá num processo de gestão democrática que possibilitará a pesquisa, a produção coletiva, a elaboração de projetos político-pedagógicos e a montagem de oficinas por área e por projetos interdisciplinares.

Iniciando o estudo das escolas ${ }^{1}$, objeto desta pesquisa, na Escola Municipal Ângela Martins - EMAM o grupo de docentes do $3^{\circ}$ ciclo foi composto por nove professores e uma coordenadora pedagógica. Desse modo, o grupo-referência da pesquisa, nessa escola, foi constituído por dez professores. Já na Escola Municipal Lúcia de Freitas - EMLF o grupo de docentes do $3^{\circ}$ ciclo foi composto por treze professores e uma coordenadora pedagógica, totalizando, assim, quatorze docentes pesquisados nessa escola.

Com relação à sua formação acadêmica, na EMAM, os dez docentes pesquisados eram graduados, sendo que dois deles estavam concluindo a pós-graduação latu sensu. Na EMLF, todos os quatorze professores possuíam, também, curso superior; dois deles tinham pós-graduação latu sensu e um possuía curso de aperfeiçoamento. Isso comprova que as escolas tinham um corpo docente qualificado o que, sem dúvida, lhes trazia ganhos, considerando-se a formação inicial como fator importante na formação docente.

Quanto à participação dos professores em projetos de formação continuada, todos participaram do projeto de formação em serviço oferecido nas duas escolas. Já a participação deles nos projetos da Rede Municipal foi representativa. Aqueles que participavam desses cursos tinham a tarefa de repassar aos colegas os ensinamentos recebidos, o que nem sempre era viável. Foi baixo o índice de participação dos docentes, nas duas escolas, em cursos de formação por eles escolhidos. Um dos motivos pode ter sido o fato de a maioria cumprir jornada dupla na rede.

Constatou-se que quando uma escola optava pela formação docente no cotidiano do trabalho ela ficava compromissada com um processo contínuo e dinâmico, envolvendo cooperação pedagógica entre professores e coordenadores. Contando, ainda, com assessoria pedagógica esses profissionais exerciam o papel de interlocutores, oferecendo aos professores suporte em seu processo reflexivo.

Nos últimos anos, tem-se expandido o número de escolas que desenvolvem projeto de formação docente no cotidiano do trabalho escolar.

${ }^{1}$ Adotamos nomes fictícios para as escolas e para os professores citados no artigo. 
Uma das principais metas desse projeto é diminuir o fracasso escolar. Assim, atividades formativas para professores e coordenadores pedagógicos têm sido implementadas. Tal estratégia é enfatizada por alguns autores que vêem a escola como locus para a formação do professor em serviço (Kramer, 1989, 1995; Mendonça, 1991 e Mediano, 1992).

Verificou-se que a formação continuada dos professores, no que se refere aos aspectos inovadores da proposta, se confrontava com uma série de obstáculos. A superação deles exigia: vontade política, atuação de um profissional capaz de trabalhar, no coletivo e interdisciplinarmente, no desenvolvimento de projetos, além da formação de um pesquisador crítico e reflexivo.

Em contrapartida, os documentos das escolas, registros e memória dos professores em seus espaços-tempos de formação atestam que a formação no processo de trabalho surgiu, basicamente, para atender a necessidade de preparar o professor para enfrentar os desafios da prática.

Eis o que relata este trecho de um documento da EMAM:

"[...] Este registro tem o objetivo de sistematizar as diversas ações e reflexões a respeito do projeto de formação de educadores em construção pelos professores da EMAM. Gostaríamos de enfatizar que estamos inseridos num contexto de experiência pedagógica, o Projeto Escola Plural, buscando a construção da autonomia dos educadores em seus processos de formação, criando novas práticas de ensino e aprendizagem e pensando novas formas de construção curricular e produção de conhecimentos. As experiências aqui relatadas são o testemunho do diálogo entre os grupos de professores dos turnos da manhã e da tarde, numa iniciativa de pesquisar a própria prática, numa caminhada e tentativa de construção dos princípios da Escola Plural." (Projeto de Formação EMAM, Professores em Formação, p. 2)

O trecho a seguir do Projeto Político-Pedagógico - PPP da EMLF, no item 10, trata da formação docente:

"[...] A formação do corpo docente será feita prioritariamente dentro da escola, com a participação de todos dos professores. Essa formação deverá considerar a realidade do trabalho desenvolvido e as dificuldades e limites presentes no contexto da escola como também considerar as sugestões dos docentes no coletivo de seus respectivos ciclos." (PPP, Princípios para a Formação de Professores na EMLF, p.27)

Os documentos pesquisados fazem referência à formação docente, defendendo a sua realização dentro da escola, prioritariamente, com a participação de todos os professores e aprovam, também, investimentos na 
formação em serviço para todos os professores, a partir da realidade dos ciclos e das necessidades dos alunos.

Pôde-se perceber, na análise dos dados, que os professores iniciaram essa experiência de formação se perguntando o que gostariam de tratar, apontando suas necessidades, dilemas, temas de interesse. Dos temas propostos, foram destacados o estudo da avaliação formativa e a intervenção pedagógica. Segundo eles, queriam transformar a sua prática pedagógica. Implícito aos temas, estava presente o desejo de mudança, de confirmação de uma proposta construída que buscasse novas estratégias, pois tinham certeza de que estavam no caminho certo.

Alguns depoimentos ${ }^{2}$ dos professores:

"Nós estamos pensando a nossa formação. Aproveitamos o tempo coletivo para discutir as questões que nos afligem. Não acho certo a regional preparar o projeto sem nos consultar. Temos as nossas demandas e elas são decididas no coletivo." (Prof. James, Geografia, $3^{\circ}$ ciclo, EMAM)

"Na minha opinião, formação para alguns fora da escola não funciona. Esse professor tem a tarefa de repassar as contribuições para os colegas, mas não temos tempo suficiente para isso. Acredito na formação organizada na escola, quando todos estão juntos. Discutindo os problemas, definindo as prioridades." (Prof. Pedro, Português e Inglês, $1^{\circ}$ ano, $3^{\circ}$ ciclo, EMLF)

Isso permitiu que as escolas pesquisadas iniciassem um trabalho voltado para a relação teoria-prática, numa visão de unidade, como preconizam Candau e Lelis (1990, p. 55): "é indispensável que a teoria tenha nascido de uma prática real naqueles a quem se dirige, que seja tomada a consciência da prática ou, pelo menos, dos sentimentos que os animam e que eles gostariam de ver encarnados na prática".

Observou-se, ainda, que, para o desenvolvimento dessa experiência, de modo geral, os professores optaram pelo trabalho coletivo. Muito pouco era feito individualmente. $\mathrm{O}$ grupo era continuamente dividido em pequenos grupos de três ou quatro professores. Após algum tempo de trabalho, voltavam a se reunir com os demais. Como afirma Kramer (1995), eles iam aprendendo uns com os outros e construíam um conhecimento que julgavam necessário. Contudo, isso exigiu algumas condições: adoção de procedimentos participativos e de diálogo em que o professor era ouvido, quer pelos colegas, quer pelo assessor do encontro. Aliás, os assessores escolhidos pelos professores para o processo de capacitação

2 Todas as transcrições das falas dos professores, neste trabalho, estão apresentadas na íntegra.

Estudos em Avaliação Educacional, v. 16, n. 32, jul./dez. 2005 
faziam isso com muita propriedade. Além de serem muito bem aceitos pelo grupo, eram vistos como profissionais que poderiam contribuir dialogando, provocando reflexões, ajudando-os a compreender as múltiplas tessituras ${ }^{3}$ do ensinar e do aprender.

Quanto à forma e estratégia de participação dos assessores no processo de formação continuada, observei que eles orientavam as discussões dos professores em pequenos grupos e no coletivo, e esse acompanhamento era feito mensalmente, ao passo que as discussões dos professores eram feitas nos encontros que eles tinham semanalmente.

Nesses espaços de trabalho coletivo, os docentes da EMAM sempre se mostraram ansiosos quanto à questão da avaliação. Optaram pela discussão da avaliação vinculada ao currículo. A partir daí, sentiram a necessidade de refletir sobre a prática pedagógica da escola e de dialogar com alguns assessores que pudessem ajudá-los a construir novas categorias de pensamento, necessárias para conceber a avaliação formativa.

A seguir, um trecho das notas de campo a esse respeito:

"Assessora 1: Acho um avanço o fim da nota como avaliação. A prova e a nota são típicas do modelo tradicional. [...] Professor 1: O que podemos mudar em nossas avaliações? [...] Professor 2: E ainda temos que definir as prioridades do $3^{\circ}$ ciclo [...] Assessora 2: Até hoje existe uma lacuna. O que definir como prioridade em cada ciclo de formação? As ciências são importantes na medida em que trazem os métodos. Noções de tempo, espaço e causalidade são fundamentais no processo de alfabetização. São categorias do real [...] Professor 3: Quanto à avaliação, às vezes é difícil porque implica juízo de valor. É de grande responsabilidade. Para avaliar é preciso acompanhar o aluno. Registrar o que ele aprendeu e o que não aprendeu. Precisamos superar a lógica conteudista, mas jamais abolir os conteúdos [...]." (Notas de Campo, Preparação do II Congresso da Escola Plural, Tema: Currículo e Avaliação, 05/10/02, EMAM)

Já a EMLF desenvolveu, inicialmente, um curso de doze horas sobre o tema avaliação. A discussão curricular prosseguiu, pois a mudança nas formas de avaliação implicava repensar toda a organização escolar e a forma como professores e alunos relacionavam com o conhecimento. Acerca desse encontro, registrei:

3 O termo tessituras foi utilizado para caracterizar as relações desenvolvidas pelos professores. Nos espaços-tempos escolares os professores construíram, planejaram, organizaram o fazer docente, teceram a trama dessas relações a partir de múltiplos fios e, assim, deram um novo sentido ao cotidiano e às práticas pedagógicas. 
"[...] Partindo dessas questões, o coletivo da escola propõe: que a avaliação seja contínua e descritiva e que o registro da mesma aconteça em duas etapas: uma no primeiro semestre e a outra no segundo; que no final de cada semestre seja feito um registro sobe cada aluno no Caderno da Turma, a partir das anotações realizadas pelo professor. Estamos aprendendo a avaliar numa perspectiva formativa, portanto: que os estudos sobre a questão da avaliação possam ter continuidade, cabendo a cada professor contribuir com a sugestão de subsídios e se preparar para participar das discussões nos encontros coletivos." (Notas de Campo, 13/09/02, Encontro de Professores: Avaliação Escolar, EMLF)

O processo de formação continuada também foi avaliado nas duas escolas. A EMAM, em geral, realizava a avaliação no final do encontro em plenário. Um professor registrava as opiniões dos professores. Já a EMLF utilizava a avaliação individual, manuscrita em folha de papel. No final dos encontros e seminários, os professores apresentavam suas impressões sobre o trabalho, oralmente e por escrito. As opiniões eram sistematizadas e utilizadas nos encaminhamentos posteriores. Quando necessário, reformulavam os procedimentos adequando-os às necessidades do grupo. O trecho abaixo, retirado das notas de campo, mostra a síntese de um encontro:

"Nas avaliações dos encontros os professores procuravam valorizar o conteúdo, a metodologia, a troca de experiências e o conhecimento de novas experiências. Dentre as principais discussões, destaco reflexões em torno de questões, como: Avançamos nas discussões? Que definições retiramos desse encontro? Quais são os próximos passos? Quem colabora na sistematização dos aspectos mais importantes?" (Notas de Campo, 20/10/02, Encontro de Professores, EMAM)

Em seus trabalhos, Zeichner ${ }^{4}$, abordando o conceito de professor reflexivo, lembra que esse conceito pode significar coisas diferentes. "A pergunta não é se os professores são reflexivos, mas como estão refletindo e

\footnotetext{
4 Zeichner (1990, 1993) defende um programa de formação continuada que prepare o professor a fim de que tenha perspectivas críticas sobre as relações entre a escola e as desigualdades sociais. Portanto, esse enfoque enfatiza três aspectos fundamentais: a aquisição, por parte do docente, de uma bagagem cultural de orientação política e social; o desenvolvimento de capacidades de reflexão crítica sobre a prática e o desenvolvimento das atitudes que requer o compromisso político do professor como intelectual transformador na aula, na escola e no contexto social. Portanto, acredito ser importante atitudes de busca, de experimentação e de crítica, de interesse e trabalho solidário, de generosidade, de iniciativa e colaboração, estratégias estas propícias para um trabalho coletivo.
} 
sobre o que estão refletindo" (2000, p.12). Baseando-se no trabalho de Dewey (1933), Zeichner ressalta que uma ação reflexiva apóia-se em um ativo desejo de analisar vários aspectos de uma questão, dar atenção aos fatos e buscar alternativas diferentes. É a antítese da aceitação acrítica da ordem existente da escola. Engloba uma abordagem crítica dos rótulos oficiais e dos significados da cultura escolar. Ao refletir, deve-se examinar, continuamente, os fundamentos educacionais que estão sob o que ordinariamente é tido como natural e certo (Zeichner, 2000).

Os depoimentos dos professores mostram como eles identificam as dificuldades de aprendizagem dos alunos:

"Identifico as dificuldades de aprendizagem nos alunos ao perceber que o adolescente não consegue compreender a solicitação feita, apesar de ser orientado individualmente, não consegue realizar a atividade, revela dispersão, desconcentração, muitas vezes perturba o desenvolvimento das atividades. Isso as vezes acontece com os outros professores também." (Prof. Mateus, Inglês, $3^{\circ}$ ciclo, EMAM)

"Eu identifico as dificuldades de aprendizagem através de uma avaliação formativa, da observação realizada continuamente sobre os processos de desenvolvimento do aluno em todos os aspectos: sócio-afetivos, cognitivos e culturais, dou ênfase na construção da leitura e da escrita, também estamos preocupados com a construção do pensamento lógico-matemático." (Prof ${ }^{a}$ Narla, História, $3^{\circ}$ ciclo, EMAM)

Nessa perspectiva, a idéia da reflexão como prática defendida por Zeichner (1993, p. 23) parece contribuir mais de perto para a construção do sentido do trabalho docente. $\mathrm{O}$ autor valoriza a interação dos membros do grupo, pois os professores podem se apoiar mutuamente, sustentar o crescimento uns dos outros, olhar para os próprios problemas, compreender que eles têm relação com os problemas dos outros professores, com a própria estrutura da escola ou do sistema educativo.

Prosseguindo a reflexão sobre o trabalho docente, para traçar um esboço da questão do saber docente ${ }^{5}$, recorro às contribuições de Tardif, Lessard e Lahaye (1991). Segundo esses autores, certamente o professor

\footnotetext{
5 Outros estudos buscam dar conta da complexidade e especificidade do saber constituído no e para o exercício da atividade docente e da profissão (Enguita, 1991; Popkewitz, 1995; Pérez Gómez, 1995; Lüdke, 1995, 1996, 1998). Esses autores têm se debruçado sobre a questão dos saberes que os professores mobilizam quando ensinam, buscando identificar aspectos e características de seus trabalhos que representam, no meu entender, contribuições bastante significativas, bem como algumas diferenças percebidas em suas proposições e análises.
} 
sabe alguma coisa, mas o quê precisamente? O professor sabe identificar quando o aluno aprende? Quando o aluno necessita de intervenção? Desenvolve saberes para implantar uma avaliação formativa?

Essas questões remetem-me aos seguintes comentários dos professores sobre o trabalho desenvolvido por eles:

"Procuro entender as dificuldades de aprendizagem como sintomas que emergem de um processo, e tal como a aprendizagem é resultado de uma construção. Acredito que as causas desses sintomas podem estar na tentativa de homogeneização do ensino e nas dificuldades da escola trabalhar com a diversidade e a complexidade do ser humano." (Prof ${ }^{a}$ Sônia, Ciências, $3^{\circ}$ ciclo, EMAM)

"Para trabalhar com as diferentes formas de aprender dos alunos tenho como princípio: respeito às diferenças, flexibilidade nos agrupamentos de alunos, flexibilidade nas atividades, respeitando as habilidades de cada um, intervenção processual, e, na medida do possivel, um atendimento mais individualizado para atender aos alunos com mais necessidades." (Prof ${ }^{a}$ Vera, Língua Portuguesa, $3^{\circ}$ ciclo, EMAM)

"Estou percebendo crescimento, maior maturidade da parte dos alunos. Isso não quer dizer que seja fácil. Mas pelo menos o meu agrupamento de professores está sintonizado. Procuramos trabalhar integrado. Com isso dividimos as responsabilidades e somamos a colaboração de todos. Estamos aprendendo na prática, no embate da sala de aula." (Prof ${ }^{a}$ Hilda, Português e Filosofia, $3^{\circ}$ ano, $3^{\circ}$ ciclo, EMLF)

Cotidianamente, os professores partilhavam, uns com os outros, seus saberes mediante as atividades que produziam, modos de fazer e de organizar a sala de aula, de preparar atividades de intervenção e de avaliação processual, etc. Trocavam informações sobre os alunos e dividiam um saber prático sobre sua atuação.

Mas os saberes também eram partilhados quando, em conselhos de classe, por exemplo, os professores tomavam decisões importantes sobre a forma de acompanhar o aluno, ou quando construíam juntos materiais ou elaboravam avaliações. Enfim, partilhavam experiências e desafios. Ainda que essas atividades de partilha dos saberes fossem consideradas como responsabilidade profissional pelo professor, a maior parte delas expressava a necessidade de troca de experiências. Assim, os encontros pedagógicos, conselhos de classe, como também as reuniões semanais foram mencionados pelos professores como lugares privilegiados de trocas.

Duas professoras se posicionaram a esse respeito: 
"Temos trabalhado muito no sentido de priorizar no $3^{\circ}$ ciclo algumas habilidades: leitura, escrita, comunicação, raciocínio lógico [...] Alguns alunos avançam. Outros nos preocupam. Precisamos de mais apoio. Defendo um serviço de rede que atenda os alunos em suas necessidades." (Prof ${ }^{a}$ Vera, Língua Portuguesa, $3^{\circ}$ ciclo, EMAM)

"Estamos preocupados com os alunos que estão concluindo o $3^{\circ}$ ciclo e não atingiram os objetivos propostos. A intervenção tem que ser mais abrangente, extra turno. A intersetorialidade 6 ainda não funciona na Rede Municipal. Esses alunos precisariam de continuidade e nós não temos condições de acompanhá-los. Alguns precisam até ficar mais tempo conosco. Como resolver isso?" (Prof ${ }^{a}$ Mara, Matemática, Ciências e Filosofia, $2^{\circ}$ ano, $3^{\circ}$ ciclo, EMLF)

Observou-se, também, nas escolas, a utilização de metodologia participativa, dialogal. $\mathrm{O}$ trabalho coletivo era visto como principal fonte de construção do conhecimento. Às vezes, desenvolviam estratégias que pretendiam explorar com seus alunos. Tais estratégias eram importantes não apenas como fonte de crescimento, mas também pela troca de experiência entre eles. Como diz Kramer (1989), entende-se que os mecanismos de formação de professores em serviço devem ser percebidos como prática social inevitavelmente coerente com a prática que se pretende implantar na sala de aula entre professores e alunos.

Deve-se assinalar, ainda, que, ao longo dos encontros, os professores procuravam criar também um clima de confiança entre os participantes, clima esse manifestado pela coragem de expor suas experiências, seus dilemas e questionamentos. Enfim, compreendiam e vivenciavam o princípio da interação e reflexão. Assim, desenvolviam a autonomia e a criatividade, conjugadas à solidariedade entre eles. Desse modo, esses encontros eram oportunos para o confronto de práticas e idéias. Isso contribuiu para o crescimento profissional do grupo. Assim, com base em procedimentos participativos, os professores adotaram a pedagogia da pergunta, como preconiza Freire (1985): “Uma pergunta adequada, no momento certo, faz refletir e avançar no conhecimento".

Com efeito, conclui-se que esse trabalho coletivo favoreceu a construção dos espaços-tempos de capacitação dos professores e, conseqüentemente, a sua capacidade de análise crítica. Ademais, a

${ }^{6}$ A intersetorialidade entre as políticas públicas da área social (Conselhos/Posto de Saúde/Serviço de Assistência, Centros Culturais, Serviços de Segurança, etc.) foi uma proposta defendida pelos professores a fim de buscar maior articulação e resultados efetivos no trabalho junto à comunidade. 
observação dos professores em seus espaços-tempos de formação, no cotidiano do trabalho, com a assessoria de professores doutores escolhidos por eles, permite concluir que a escola é, sem dúvida, o local por excelência para trabalhar a formação de professores em serviço. Tal afirmação deve-se ao fato de todos passarem pelo mesmo processo, discutirem as mesmas questões e se capacitarem coletivamente para as transformações almejadas.

Dessa forma, pode-se concluir que o processo de capacitação, no cotidiano do trabalho, ocorrerá, efetivamente, se o coletivo explicitar seu desejo por ela e se contar com uma direção comprometida com a transformação e disposta a acompanhar os professores nessa caminhada. Nesse sentido, observou-se, nas duas escolas, que a direção, na busca desse crescimento, incentivava os professores e, sobretudo, valorizava o trabalho deles. Um trabalho dessa natureza leva ao repensar contínuo da proposta pedagógica da escola. Foi isso que aconteceu nas escolas pesquisadas. De acordo com seu estilo e condições, após encontros e discussões, cada grupo de professores conscientizou-se das modificações necessárias à sua prática pedagógica e, então, definiram essas mudanças no PPP. Iniciaram, assim, no coletivo, um processo de articulação prática desses desafios.

Dalben (1998), em sua tese de doutorado, destacou a avaliação como um processo de formação do professor no trabalho escolar. Apontou os inúmeros movimentos de reflexão/avaliação desencadeados pelo processo de implantação da Escola Plural. Reconheceu que todos os processos de reflexão das práticas pedagógicas e sobre as práticas, mais avançados ou não, favoreceram um processo de formação dos profissionais no seu próprio local de trabalho.

A esse respeito, na visão dessa autora, o professor, no espaço de trabalho, deve adquirir domínio das teorias pedagógicas sobre o processo de ensino e didática para desenvolver uma ação educativa compreensiva. Os textos a respeito são poucos e as orientações superficiais. "Embora a assessoria se empenhasse o tempo todo na formação do professor, a direção era, prioritariamente, na perspectiva do aluno como sujeito da aprendizagem, e quase nunca do professor, como sujeito da aprendizagem sobre a prática pedagógica e o processo de ensino" (Dalben, 1998, p. 194).

Por meio dos dados coletados, percebeu-se o que os docentes almejavam com esse projeto de formação. Em síntese seria: valorizar a formação continuada; análise teórico-prática com o objetivo de promover as mudanças necessárias na prática pedagógica; revelar a condição dos professores como atores inseridos nos processos de construção e condução dos princípios educativos da Escola Plural e articular experiências, projetos 
pedagógicos, estratégias de intervenção, produzindo, assim, registros e a memória da escola.

Desse modo, constatou-se que os professores aceitavam a mudança e consideravam importante implementar, na escola, um processo de formação no cotidiano escolar. Percebeu-se, pois, que o projeto de formação dos professores emergia das suas necessidades reais. Participando desses encontros de formação, observou-se que os projetos calcavam-se, fundamentalmente, na discussão dos desafios da prática pedagógica em busca de caminhos alternativos. Nessas discussões, logo surgiu a necessidade de uma formação pedagógica mais consistente. Nas reflexões preliminares a esse respeito, foi pontuado que o principal problema da escola era a alfabetização dos alunos na perspectiva do letramento. Este era o desafio que enfrentavam no cotidiano, pois os alunos, ao longo de sua trajetória escolar, apresentavam diferentes níveis de leitura e escrita.

Alguns depoimentos dos professores da EMAM:

"Hoje, nós vamos continuar as discussões sobre currículo e avaliação. Vamos tentar fechar as questões propostas no encontro anterior. Se der tempo a gente discute a proposta de Alfabetização no $3^{\circ}$ ciclo." (Prof ${ }^{a}$ Vera, Língua Portuguesa, $3^{\circ}$ ciclo)

"A gente avalia o processo. Quando decidimos mudar assumimos isso. Respeitamos o aluno como sujeito em processo de desenvolvimento. Ele é tratado com respeito e o nosso trabalho procura envolver as dimensões: cognitivas, afetivoemocional, sociocultural e corporal." (Prof ${ }^{a}$ Denise, Educação Artística, $3^{\circ}$ ciclo)

Outros depoimentos dos professores da EMLF:

"Nós, professores do $3^{\circ}$ ciclo, temos um grande desafio: aprender a alfabetizar, construir novas estratégias de intervenção para que nossos alunos desenvolvam e sejam letrados. Para isso, é fundamental garantir tempo para a formação em serviço. É ai que vamos buscar suporte para esse trabalho." (Prof ${ }^{a}$ Marta, Português, Educação Artística e Filosofia, $2^{\circ}$ ano, $3^{\circ}$ ciclo)

"Já há algum tempo que nós estamos nos perguntando: que tipo de aluno temos? Quem somos? Que tipo de escola nós queremos construir? Que tipo de aluno nós queremos formar? Aí chegamos à conclusão que se tinha que discutir currículo, avaliação, docência. Tudo isso fez com que a gente reconstruísse o projeto políticopedagógico da escola, estamos caminhando [...]." (Prof. Fábio, História e Geografia, $3^{\circ}$ ano, $3^{\circ}$ ciclo) 
Magalhães e Tancredi (2002) enriquecem essa idéia de formação na própria escola. Defendem a construção de espaços de formação continuada no próprio local de trabalho, espaços de discussão e reflexão permanente entre pares, no coletivo da escola. Nesses espaços, questões como elaboração e discussão da implementação de políticas públicas, relações interpessoais na sala de aula e na escola, explicitação e análise das concepções e valores dos docentes e demais agentes educativos, conhecimento, aceitação e atendimento à diversidade cultural dos alunos, estreitamento da relação escola-família, papel dos professores e dos pais em contextos de mudança podem ser analisadas e discutidas.

Coerentes com essa proposta, a formação no cotidiano do trabalho aparece como uma estratégia de transformação, se for assumida como desejo dos professores. E, assim, contribui para que o professor refleta sobre sua prática de avaliação e acompanhe a busca coletiva de soluções para inúmeros desafios.

Portanto, nessas experiências, a formação continuada orientava-se inteiramente para a intervenção nas escolas. Trata-se de trabalhar na junção de dois aspectos: a intervenção pedagógica no cotidiano escolar e responder às necessidades de formação, próprias de uma equipe pedagógica. Para tanto, integraram novas dimensões à reflexão sobre a formação no cotidiano do trabalho, a saber: a reflexão sobre as práticas de intervenção e avaliação, o trabalho em equipe e o projeto pedagógico.

Assim, ao analisar os dados das duas escolas, verificou-se que a formação dos professores nos espaços-tempos da escola é, pois, uma alternativa que se tem mostrado viável para o seu desenvolvimento profissional. Tal estratégia significa investimento na escola vista como espaço coletivo privilegiado de formação profissional, possibilitando mudanças que podem favorecer a construção de práticas pedagógicas inclusivas, voltadas para o atendimento das características sociais e culturais da comunidade e para as necessidades educativas dos alunos (Mizukami et al., 2002).

Tais análises confirmam mudanças no foco da formação dos professores. Eles, no cotidiano do trabalho, estão em busca de informações, conhecimentos e formam-se na prática, vivenciando e partilhando suas experiências docentes. 


\section{OS PROFESSORES NOS ESPAÇOS-TEMPOS DE AVALIAÇÃO FORMATIVA}

Em seu PPP, os docentes da EMLF chegaram a definir uma linha para a avaliação escolar. Afirmaram que ela deveria considerar como eixo o processo percorrido pelo aluno na construção do conhecimento e não somente o produto. Deveria ser, portanto, contínua, dinâmica e investigativa.

Alguns depoimentos dos professores sobre a avaliação:

"A Escola Plural tem muitos pontos positivos. Avaliação mais aberta, concepção mais ampla. Conteúdo e acompanhamento precisam estar presentes. Não significa soltar a corda e deixar o aluno à vontade." (Prof ${ }^{a}$ Hilda, Português e Filosofia, $3^{\circ}$ ano, Turma Projeto, EMLF)

"Eu avalio observando o desempenho da turma, observando o comprometimento individual. Por enquanto não estou aplicando provas. Aplico exercícios, recolho, dou retorno para os alunos. Sinto que eles não estão preparados para fazer avaliação sem consulta ${ }^{7} . "$ (Prof ${ }^{a}$ Ivana, Português e Inglês, $1^{\circ}$ ano, $3^{\circ}$ ciclo, EMLF)

"Eu sou tradicional, dou provas mais ou menos uma vez por mês. Aplico exercícios em sala de aula e realizo correções coletivas." (Prof. Daniel, Matemática, $1^{\circ}$ ano, $3^{\circ}$ ciclo, EMLF)

"Existem visões bem diferenciadas quanto à avaliação. Percebo que ainda estão presos a uma avaliação somativa. Está presente uma dificuldade para uma prática mais formativa." (Prof ${ }^{a}$ Elza, Coordenadora Pedagógica, $3^{\circ}$ ciclo, EMLF)

7 A professora fez referência ao processo vivenciado pelas escolas. A Rede Municipal de Belo Horizonte passou a integrar o Sistema Mineiro de Avaliação da Educação Pública Simave. Dessa forma, o Programa de Avaliação da Rede Pública de Educação Básica Proeb faz parte do Simave e tem como objetivo avaliar a rede de ensino, produzindo resultados por escola. Segundo os seus idealizadores, trata-se de produzir um conjunto de informações que possibilite à escola trabalhar o seu diagnóstico e implementar as ações para a correção de rumos no processo educativo, sempre que necessário. Em 2002, na semana de 30 de setembro a 04 de outubro, foram aplicados testes de Língua Portuguesa, com ênfase na leitura e compreensão de texto, em todos os alunos da rede municipal que estavam cursando os períodos escolares correspondentes à metade e ao final do ensino fundamental. Assim, o $3^{\circ}$ ano, do $3^{\circ}$ ciclo, participou da avaliação. 
Mas constatei que os docentes tinham consciência da necessidade de mudar o foco da avaliação tornando-a mais formativa ${ }^{8}$. Percebi que eles sentiram a importância desse processo de avaliação uma vez que, pelo registro das dificuldades do aluno, era possível ter o retrato do desenvolvimento do aluno em relação a si mesmo e aos objetivos propostos. Para isso, em sua prática, os professores pesquisados optaram pela elaboração do Caderno da Turma e nele registravam os dados relativos ao desempenho dos alunos.

Eis alguns depoimentos:

“Olha, eu me identifico com a proposta de avaliação da Escola Plural. Sou contra a reprovação. Estava passando da hora de mudar o estilo de avaliação. A prova existe, mas ela é um dos instrumentos. Nós também abolimos a nota." (Prof. Pedro, Português e Inglês, $1^{\circ}$ ano, EMLF)

"Acho que a avaliação serve para acompanhar o aluno no dia-a-dia. Ajuda o professor a conhecer a turma e saber sobre o desenvolvimento do aluno. Saímos de um modelo fechado. Agora temos liberdade, mas faltam parâmetros mais claros para o $3^{\circ}$ ciclo." (Prof ${ }^{a}$ Mara, Matemática, Ciências e Filosofia, $2^{\circ}$ ano, EMLF)

Em seus depoimentos, os docentes afirmaram que deveriam ser registrados os progressos e as dificuldades de cada aluno, evitando-se os conceitos e notas que não expressassem o processo de aprendizagem do educando. Portanto, esses registros serviam de referência para que os professores replanejassem a sua ação pedagógica.

Verifiquei a ocorrência de concordância entre os professores quanto ao caráter formativo dos instrumentos de avaliação e que também o professor deveria evitar o predomínio de punições. Segundo eles, os instrumentos de avaliação formativa servem para organizar o conhecimento, diagnosticar o que o aluno sabe e o que ainda não sabe. Nesse sentido, a avaliação só tem sentido quando provoca o desenvolvimento do educando, proporcionando-lhe momentos de aprendizagem, e quando reorienta a prática do professor.

A concepção de avaliação da EMAM não se fez de forma pontual ou localizada, mas encontrava-se em todos os espaços da nova organização do

\footnotetext{
8 Um dos elementos fundamentais da concepção de educação e escola proposto pelo Programa Escola Plural é a avaliação. Nessa nova concepção de escola, avaliar não significa classificar ou sentenciar, aprovar ou reprovar. Implica, isto sim, incidir sobre aspectos globais do processo, inserindo tanto sobre as questões ligadas ao processo ensinoaprendizagem como as que se referem à intervenção do professor, ao projeto curricular da escola, à organização do trabalho escolar, à função socializadora e cultural, à formação de identidades, dos valores, da ética, enfim, do seu projeto pedagógico.
} 
trabalho na perspectiva plural. Era entendida, portanto, como um processo permanente, de caráter diagnóstico e, por isso, deveria apontar soluções para os problemas que dificultavam a aprendizagem. Os depoimentos a seguir são de professores do $3^{\circ}$ ciclo a respeito de sua experiência de avaliação no processo:

"Avalio os meus alunos através de avaliação diagnóstica, observação em sala de aula do trabalho individual, em dupla ou pequenos grupos. Aplico também provas no final da etapa e crio espaço para a auto-avaliação do aluno." (Prof. Gildo, Matemática, EMAM)

"Na avaliação é fundamental acompanhar o cotidiano da sala de aula, observar como os alunos se relacionam, cumprem sua tarefa escolar. Costumo diversificar as avaliações. Aplico prova individual ou em dupla e para os trabalhos em grupos proponho a auto-avaliação." (Prof ${ }^{a}$ Narla, História, EMAM)

Concluo, pois, que o atual processo de avaliação adotado pelos docentes é coerente com a forma de se pensar a escola, a organização de tempo e espaço, a flexibilidade na enturmação e, principalmente, a construção curricular.

No encontro de capacitação em serviço, realizado em agosto de 2002 , sob a orientação de um dos assessores, foram registrados os seguintes comentários dos professores do $3^{\circ}$ ciclo:

"Eu sou contra a cultura da nota, da reprovação. Não foi fácil para nós romper com essa lógica e até hoje somos punidos pelos pais e pela comunidade pela nossa proposta alternativa. Queremos que o nosso aluno tenha uma outra relação com o conhecimento." (Prof. James, Geografia, EMAM)

"Já há algum tempo nós estamos trabalhando muito tentando descobrir e aprender formas de lidar com esse aluno que apresenta necessidades de acompanhamento em muitas dimensões. O estudo de caso que fizemos, ajudou a entender a história de vida desse aluno. A avaliação mudou. É processual. A intervenção tem sido uma forma de acompanhar esse aluno. Mas, ainda temos muito que avançar." (Prof ${ }^{a}$ Sônia, Ciências, EMAM)

“Eu já estou aqui na EMAM há algum tempo e posso dizer que o que sustenta a nossa prática é o trabalho coletivo. E muito bom trabalhar aqui. No $3^{\circ}$ ciclo você vê que o grupo está sintonizado. Quer fazer o melhor. Estamos preocupados com a formação do aluno, então a proposta plural coincidiu com nossos objetivos. Temos discutido muito e procurado mostrar para o aluno que ele tem que estudar para aprender e não para fazer prova ou passar de ano. Aqui na escola quem estuda,

Estudos em Avaliação Educacional, v. 16, n. 32, jul./dez. 2005 
estuda pra valer. Em geral, eles também valorizam todas as atividades independente da nota. O desafio é mobilizar os que não querem porque em casa eles não estudam. Fazem porque cobramos." (Prof ${ }^{a}$ Marlene, Educação Artística, EMAM)

O que levaria um professor do $3^{\circ}$ ciclo a se posicionar com firmeza contra o modelo de avaliação classificatório? Percebi que o trabalho coletivo e as reflexões realizadas pelos professores, no coletivo do trabalho sobre a prática docente de avaliação, provocaram amadurecimento, percepção de que o modelo de avaliação classificatório não contribui, de fato, para a real aprendizagem dos alunos e, portanto, buscavam, nos espaços-tempos coletivos, novas formas de desenvolvimento do fazer pedagógico.

Concluindo, os docentes acreditavam numa avaliação com caráter formador, diagnóstico e qualitativo. O processo de avaliação foi subsidiado por instrumentos diversos que foram utilizados cotidianamente com o objetivo de diagnosticar o desempenho dos alunos ante o processo de ensino-aprendizagem, abrangendo as várias dimensões de formação (cognitiva, sociocultural, afetiva-emocional e corporal). Mas o que ainda consideravam como principal avanço era a prática coletiva da avaliação. Ela garantia que os princípios e intenções definidos coletivamente fossem respeitados, garantindo também a pluralidade de análises sobre o processo educativo.

\subsection{Construção Coletiva dos Instrumentos de Avaliação}

No que diz respeito às formas e instrumentos de avaliação adotados pela EMLF, acompanhei, por meio da observação participante, reuniões de professores do $3^{\circ}$ ciclo, atividades em sala de aula e conselhos de classe. Além disso, examinei fichas e instrumentos construídos pela escola. As atividades relativas ao processo de avaliação culminaram com a socialização dos resultados obtidos no final da primeira etapa de 2002, nas reuniões de conselhos de classe ${ }^{9}$.

Com relação à ficha de registro da avaliação, verifiquei que os docentes do $3^{\circ}$ ciclo, após estudos e reflexões, redigiram a ficha de avaliação. Essa ficha de avaliação continha, ainda, a descrição dos objetivos

\footnotetext{
9 Participaram dos conselhos de classe: alunos, pais e/ou responsáveis pelos alunos, professores da turma, coordenadores de ciclo e direção. Nesse espaço coletivo, os professores apresentaram aos pais e alunos os registros realizados durante a etapa.
} 
pretendidos para o $3^{\circ}$ ciclo e foi definida pelos professores em encontro de áreas.

Em seu projeto pedagógico, os docentes definiram que a avaliação deveria ser contínua e descritiva, com registro em duas etapas: uma no primeiro semestre e outra no segundo. E mais: o professor deveria usar regularmente o Caderno da Turma para registrar o desempenho do aluno; registro sucinto sobre cada aluno a cargo do professor-referência. Além disso, deveriam preencher a ficha oficial de avaliação do aluno no final do ciclo e incluir o tema avaliação nos encontros de formação em serviço.

O modelo de ficha de avaliação utilizado pela EMLF destacou, como elemento a ser avaliado, a auto-avaliação escrita. Nesse momento, o aluno avaliou suas atitudes considerando: o comportamento nas dependências da escola; o cumprimento dos deveres escolares; os objetivos propostos para cada disciplina e, ainda, espaço em branco para livre manifestação do aluno. A ficha de avaliação do aluno contemplou os seguintes itens: convivência em sala de aula; envolvimento no processo pedagógico e postura no processo de construção de conhecimento.

$\mathrm{Na}$ EMAM, o trabalho coletivo apresentou-se como um caminho que facilitava a construção de práticas de avaliação. Participaram desse trabalho não só o coletivo de professores, mas também os demais segmentos que interagiram com toda a comunidade escolar. Era uma prática que buscava se consolidar no cotidiano da escola. Nessa escola, a ficha de avaliação dos alunos contemplou os seguintes itens: socialização do aluno e suas interações no grupo, no trabalho pedagógico e nas áreas de conhecimento; organização da vida escolar e do trabalho pedagógico. A partir desses critérios, os professores avaliavam o aluno a fim de identificar se ele alcançara todos os objetivos, se alcançara parcialmente ou não alcançara os objetivos propostos.

Assim, os professores investiram no trabalho coletivo porque consideraram essencial reservar um tempo para a construção de práticas docentes de avaliação. Esses tempos escolares foram, portanto, construídos pela presença e ação significativa dos sujeitos que constituíram a instituição escolar.

No que diz respeito às formas e instrumentos de avaliação adotados, tanto pela EMAM como pela EMLF, tomei conhecimento deles na condição de observadora participante, acompanhando reuniões de professores, atividades didáticas nas salas de aula e conselhos de classe. Também examinei fichas e instrumentos construídos pela escola, relativos às atividades propostas no processo de avaliação que culminaram com a 
socialização dos resultados obtidos no primeiro semestre de 2002, nas reuniões de conselho de classe.

Amaral (2002, p. 6) destaca o "caráter integrante da avaliação em toda a proposta, vinculado diretamente ao processo ensino-aprendizagem e a adoção diferenciada de instrumentos" [...]. Para concretizar a dimensão contínua da avaliação, faz-se necessário lançar mão de novos procedimentos e instrumentos de avaliação: observação (acompanhada de cuidadoso registro em fichas especialmente construídas), entrevistas e conversas informais, testes, provas e trabalhos (individuais e em grupo), portfólios e auto-avaliação.

Com relação às fichas de registros de avaliações, elas foram reconstruídas pelos professores. Uma das fichas elaboradas pelo grupo de professores da escola traz o perfil da turma, as informações referentes ao desempenho da turma como um todo, as características básicas e a autoavaliação dos alunos. Apresenta, também, uma relação dos objetivos dos professores. Além desses objetivos gerais, inclui também os objetivos do professor com determinada turma em determinada etapa, a relação dos conteúdos trabalhados nos projetos, os demais conteúdos desenvolvidos e aspectos acerca da socialização do aluno.

Parece-me importante apresentar modelos de avaliações de alunos realizados pelos professores na EMLF:

"A avaliação da $1^{a}$ etapa da aluna mostra que alcançou com eficiência os objetivos propostos em: Educação Física. A aluna apresentou grandes dificuldades no processo ensino-aprendizagem necessitando de tratamento mais individualizado por parte dos professores em: Português, Inglês, Matemática, Ciências, Geografia, História. Apesar disso, tem demonstrado esforço. Quanto à convivência em sala de aula: ouve e respeita as opiniões dos colegas e professores. Quanto ao envolvimento no processo pedagógico: consegue realizar as atividades propostas com dificuldades, é freqüiente, cumpre os horários estabelecidos pela escola, nem sempre entrega as tarefas no tempo estipulado. Estabelece relações entre as informações estudadas. Utiliza a prática de observação e descrição. É capaz de organizar sinteses orais." (Avaliação de H. A. R., $1^{\circ}$ ano, $3^{\circ}$ ciclo)

"A avaliação da $1^{a}$ etapa do aluno mostra que alcançou com eficiência os objetivos propostos em: Português, Inglês, Matemática, Ciências, Geografia, História, Arte, Filosofia e Educação Física. O aluno não apresentou dificuldades no processo ensino aprendizagem. Com relação a convivência com o grupo, o aluno respeita as opiniões, sabe ouvir e participa produtivamente nas atividades e ainda contribui para o crescimento da turma. Quanto à convivência em sala de aula: ouve e respeita as opiniões dos colegas e professores. Consegue se posicionar perante o grupo, colabora com o crescimento e funcionamento do trabalho. Quanto ao envolvimento no processo pedagógico: realiza as atividades propostas, é freqüente, 
cumpre os horários estabelecidos pela escola, entrega as tarefas no tempo estipulado, organiza e realiza trabalhos individuais com iniciativa e organização. Quanto ao processo de construção do conhecimento: formula questões sobre o objeto do conhecimento a ser investigado, identifica diferentes fontes de informação (livros, filmes, documentos, jornais, revistas, enciclopédias, etc); utiliza as práticas de: observação, descrição e síntese; constrói novo sentido e referências a partir das informações trabalhadas. Estabelece relações entre as informações estudadas. É capaz de organizar sinteses orais, escritas e desenhadas." (Avaliação de M.A.N., $2^{\circ}$ ano, $3^{\circ}$ ciclo)

Coerentes com essa proposta, os professores do $3^{\circ}$ ciclo também adotaram o Caderno da Turma, que abrangia essa perspectiva. Esse caderno era considerado um instrumento capaz de auxiliar o professor no processo de avaliação e de registro do desempenho do aluno. Assim, ele poderia acompanhar a evolução do aluno, identificando progressos, desafios, entre outros. Além disso, explicitava o papel da avaliação como impulsionadora da aprendizagem.

Outras avaliações de alunos descritas pelos professores da EMAM:

"Nessa etapa foram trabalhados: medicamento genérico e similar; efeito estufa e camada de ozônio; origem dos seres vivos; diferença e semelhança entre os seres vivos; classificação dos seres vivos. O aluno não se envolveu com os temas por isso obteve pequeno aproveitamento. Tem condições de desenvolver mais na próxima etapa." (Avaliação de Desempenho de H. B. O., $1^{\circ}$ ano, $3^{\circ}$ ciclo, Ciências)

"A aluna compreende o modo de vida da Europa Ocidental entre os séculos $V$ e $X V$. Identifica esse período histórico com as propriedades que buscavam sua autosuficiência. A aluna é capaz de compreender a causa da concentração das famílias no campo na maior parte desse período conhecido como Idade Média. É capaz de reconhecer e identificar as funçōes dos principais atores sociais (senhores feudais, clero, cavaleiro e camponeses) daquele período histórico. A aluna consegue comparar a Idade Média com a nossa época, estabelecendo as semelhanças e diferenças. Portanto, a aluna atingiu os objetivos propostos para esse periodo letivo. É aplicada, tem excelente relacionamento com os colegas e professores." (Avaliação de Desempenho de M. O. G., $1^{\circ}$ ano, $3^{\circ}$ ciclo, História)

"A aluna compreende a proposta de trabalho orientada em Lingua Portuguesa. Interpreta, lê e produz textos narrativos e descritivos de gêneros variados com coerência e coesão. Quanto à linguagem oral expressa suas idéias, sentimentos e seu ponto de vista. Na produção de texto melhorou o uso das normas ortográficas. Analisa e identifica os atos de comunicação, traduz e diferencia mensagens de códigos verbal e não-verbal. Identifica emissor, receptor, código e mensagem e as 
características de jogral. Atingiu os objetivos propostos para esta etapa. Tem ótimo relacionamento com os colegas e professores, além de muito interesse pelo estudo." (Avaliação de Desempenho de S. O. C., $1^{\circ}$ ano, $3^{\circ}$ ciclo, Língua Portuguesa)

Assim, ao longo da pesquisa, utilizei esses documentos: o Caderno da Turma e a Ficha Individual. São documentos que contêm dados importantes a respeito da trajetória escolar dos adolescentes. São desencadeadores de aprendizagens tanto para os alunos como para o professor. Por meio deles, o aluno toma consciência da própria aprendizagem, reconhece suas dificuldades com a ajuda do professor e pode procurar caminhos para superá-las. Já o professor obtém informações sobre o processo de aprendizagem de seus alunos tornando a avaliação um instrumento de aprendizagem. Como instrumento de investigação didática traz informações que o auxilia na reflexão sobre o ensino e, se necessário, ele poderá reorganizá-lo.

\subsection{Procedimentos de Avaliação Adotados pelos Professores}

Nas escolas pesquisadas, os professores adotaram as seguintes categorias para avaliar os alunos: a aprendizagem de conceitos, a utilização de procedimentos, o progresso obtido nas aprendizagens instrumentais, a atitude diante do trabalho, os aspectos formais de apresentação dos trabalhos, a apreciação geral de cada aluno em relação à sua auto-avaliação e sua atitude com os colegas da turma e com os professores.

A seguir alguns registros sobre avaliação dos alunos da EMLF, realizados pelos professores no final da $1^{\mathrm{a}}$ etapa:

"A avaliação da $1^{a}$ etapa do aluno mostra que ele alcançou com eficiência os objetivos propostos em todas as disciplinas. É considerado um aluno aplicado. Quanto à convivência em sala de aula: ouve e respeita as opiniões do grupo. Consegue se posicionar perante o grupo. Colabora com o funcionamento das atividades. Quanto ao envolvimento no processo pedagógico: realiza as atividades propostas, é freqüente, cumpre os horários estabelecidos pela escola. No processo de construção do conhecimento identifica diferentes fontes de informação (livros, filmes, documentos, jornais, revistas, etc). Utiliza as práticas de observação, descrição e organiza sinteses orais, escritas e desenhadas." (Avaliação de A. R. A., $1^{\circ}$ ano, $3^{\circ}$ ciclo)

"A avaliação da $1^{a}$ etapa do aluno mostra que alcançou com eficiência os objetivos propostos em: Artes, Educação Física e Filosofia. O aluno apresentou dificuldades no processo ensino-aprendizagem, necessitando de tratamento mais 
individualizado por parte dos professores em: Matemática, Português, História e Geografia. Se evitar faltar as aulas, o aluno pode melhorar seu desempenho. Quanto à convivência em sala de aula: ouve e respeita as opiniões do grupo. Sobre o seu envolvimento no processo pedagógico: nem sempre realiza as atividades propostas, é infreqüente, não cumpre os horários estabelecidos pela escola, não revela iniciativa nos trabalhos em grupo. No processo de construção do conhecimento o aluno identifica diferentes fontes de informação e é capaz de organizar boas sinteses desenhadas." (Avaliação de E. O. S., $3^{\circ}$ ano, $3^{\circ}$ ciclo)

Vale ressaltar que a interpretação do desempenho dos alunos nas duas escolas era realizada analisando-se os diversos registros dos resultados da aprendizagem, tornando-a mais qualitativa e abolindo o sistema de medidas. Portanto, os procedimentos de registros eram mais descritivos, centrados nos aspectos qualitativos da aprendizagem.

Alguns exemplos de registros de avaliação realizados pelos professores da EMAM:

"A aluna compreende a proposta de trabalho orientada em Lingua Portuguesa, com alguma dificuldade. Demonstra certa dificuldade na interpretação e produção de textos orais, escritos, narrativos, descritivos e dissertativos em se tratando de coerência e coesão. Está aprendendo a utilizar a língua materna no que se refere aos sinais de pontuação e ortografia. Com alguma dificuldade, diferencia linguagem conotativa de denotativa, identifica, reconhece e compreende o uso das figuras de linguagem. Relaciona ritmo, verso e organização de um poema, reconhece o verso, a estrofe, soneto e rima. Posiciona-se frente à importância da literatura de cordel. Atingiu os objetivos propostos nesta etapa, parcialmente." (Avaliação de Desempenho de P.M.S., $3^{\circ}$ ano, $3^{\circ}$ ciclo, Língua Portuguesa)

"A avaliação do aluno atesta que ele apresenta dificuldades em identificar algumas características da Primeira República Brasileira. Compreende a influência dos grandes latifundiários no Estado republicano, no final do século XIX e início do século XX. $O$ aluno identifica com dificuldade o revezamento de mineiros e paulistas nos primeiros anos da República (1889-1930) e suas causas. Apresenta dificuldades para relacionar as condições sociais da maior parte dos brasileiros, com os diversos movimentos sociais (Revolta da Vacina, Revolta da Chibata, O Contestado) que eclodiram nesse período. Tem condições de se empenhar mais e estabelecer relações comparativas entre a República Velha e a atual. $O$ aluno encontra-se em processo de aquisição de conhecimentos históricos proposto para esse período. Pelo seu perfil em sala de aula pode ter melhores resultados. Quanto ao relacionamento é um bom aluno." (Avaliação de Desempenho de R. O. A., $3^{\circ}$ ano, $3^{\circ}$ ciclo, História)

A constatação de que os professores optaram por esse novo modelo de avaliação evidencia alterações significativas no processo de avaliação. 
Mas nem todos os pais as aceitaram tranqüilamente. Em seus relatos, os professores mencionaram a dificuldade de alguns pais compreenderem a linguagem dos registros e as informações sobre a trajetória dos alunos. Tal situação demonstra que os professores deveriam se empenhar, dialogando com os pais, em especial, os pais analfabetos e semi-analfabetos, estabelecendo contatos mais freqüentes com as famílias a fim de criar relação de parceria no desenvolvimento do projeto pedagógico da escola.

É importante destacar que os docentes elaboraram esses registros, cuja função foi a de reorientar o trabalho pedagógico e, assim, justificavam o seu preenchimento. Nesses registros, documentavam a vida do aluno na escola; trocavam informações entre eles para aprimorar a prática pedagógica em sala de aula; delimitavam, com precisão, os progressos dos alunos, os desafios, as necessidades e as estratégias de intervenção.

Afinal, com o empenho dos professores, mudanças nesse sentido ocorreram gradativamente. Alguns professores avançaram mais rapidamente no processo. Outros revelaram insegurança e até mesmo resistência. Permaneceu, portanto, o desafio - provocar, no aluno, uma nova maneira de se relacionar com o trabalho escolar, dentro e fora da sala de aula, adquirindo novos conhecimentos de forma contínua e novo sentido para a aprendizagem, já que haviam desaparecido os indicativos de controle nas relações pedagógicas expressos pela nota e pela reprovação.

\section{TECENDO SABERES DOCENTES: OS PROFESSORES SE FORMAM NAS PRÁTICAS DE AVALIAÇÃO}

No cotidiano escolar, o professor é desafiado a desenvolver, progressivamente, saberes oriundos do próprio processo de trabalho. E é exatamente o desenvolvimento desses saberes que exige do professor tempo, prática, experiência, etc. Identificou-se, portanto, nas escolas analisadas, as relações entre o tempo, a prática e a aprendizagem dos saberes adquiridos pelos professores que atuam no ensino fundamental. Em outras palavras, esse trabalho pretendeu averiguar se esses saberes, oriundos da própria prática do professor, são empregados na prática cotidiana da sala de aula para resolver os desafios presentes no exercício profissional dando sentido às situações de trabalho que lhes são próprias.

Sobre os saberes da prática, assim se manifestaram os professores:

"Estamos estudando sobre currículo, avaliação, projeto pedagógico tudo isso pra ver se a gente melhora o trabalho na escola. Queremos ter uma linha de trabalho nossa." (Prof ${ }^{a}$ Narla, História, $3^{\circ}$ ciclo, EMAM) 
"Vejo que nesse novo modelo de avaliação, acompanhar o aluno é fundamental. É processo [...] é isso, é a gente olhar no dia-a-dia, em todas as tarefas que o aluno faz, saber como ele vai. Conhecer o aluno, nós conhecemos. Falta é tempo para agir. Mais intervenção em sala de aula e fora dela." (Prof. Gildo, Matemática, $3^{\circ}$ ciclo, EMAM)

"Еu mudei o meu jeito de avaliar. Estou aprendendo a questionar o meu trabalho. Antes quando o aluno tirava nota baixa a culpa era dele. Não estudou. Agora, nós estamos procurando utilizar diversas formas para esse aluno aprender." (Prof ${ }^{a}$ Edna, Geografia, $1^{\circ}$ ano, EMLF)

“De tanto a gente pensar sobre a prática, partilhar nossos sucessos e angústias nós estamos aprendendo a lidar com esse aluno. Mudou muita coisa: a forma da gente olhar para o aluno, a forma da gente ensinar, a forma da gente avaliar, também." (Prof ${ }^{a}$ Amélia, Educação Física e História, $1^{\circ}$ ano, EMLF)

Dentro dessa perspectiva, reflexão e processo passaram a constituir, nos últimos anos, o eixo de uma nova tendência na formação considerada como meio de construção de saberes e identidade profissional. O trabalho coletivo estimula uma visão crítico-reflexiva, fornece aos professores os meios para desenvolver pensamento autônomo e facilita as dinâmicas de autoformação participada. Estar em formação implica um investimento pessoal, um trabalho livre e criativo com vistas à construção de uma identidade, que é também uma identidade profissional.

No caso deste estudo, percebeu-se o professor como mobilizador de saberes profissionais em sua trajetória. Ele construía e reconstruía seus conhecimentos em diferentes contextos e tempos, conforme os desafios da prática docente.

Depoimento de uma professora da EMLF:

"Tem hora que eu me pergunto como conseguimos trabalhar com essa turma? Eles vieram do $2^{\circ}$ ciclo com muitos desafios a serem superados. Não fomos preparados para tanto [...] Fomos adquirindo um saber para enfrentar esses problemas na prática, no agrupamento de professores um colaborava com o outro. E hoje, vejo que valeu a pena [...]." (Profa Marta, Português, Educação Artística e Filosofia, $2^{\circ}$ ano, $3^{\circ}$ ciclo)

Outro professor da EMLF também falou sobre os saberes tecidos na prática:

"Tem sido desafiante o trabalho no $3^{\circ}$ ciclo porque temos que recriar formas para atingir o aluno, desenvolver habilidades de leitura, escrita e raciocinio, além de 
trabalhar com atitudes, despertar esse adolescente para o exercício da cidadania. Tudo isso vem exigindo muito de nós professores. O que conseguimos fazer é fruto de uma articulação coletiva e compromisso pessoal de muitos." (Prof. Daniel, Matemática e Filosofia, $1^{\circ}$ ano, $3^{\circ}$ ciclo)

Como atestam esses depoimentos, os saberes profissionais dos professores revelam-se, portanto, plurais, heterogêneos, pois trazem à tona, no próprio exercício do trabalho, conhecimentos e manifestações do saberfazer e do saber-ser bastante diversificados, provenientes de fontes variadas. Vários autores tentaram ordenar essa diversidade, propondo classificações ou tipologias relativas ao saberes dos professores: Raymond (1993), Gauthier (1998), Martins (1998) e Tardif (2002).

Prosseguindo o estudo da formação no cotidiano das escolas, a proposta girava em torno de estudos que ajudavam na discussão das possíveis causas do fracasso escolar. Assim, eram propostos temas que possibilitavam a reflexão da prática pedagógica no $3^{\circ}$ ciclo, ou seja, currículo, intervenção, avaliação formativa, entre outros. Também os docentes se agrupavam por ciclos e estabeleciam uma dinâmica de relato e estudo dos casos de alunos. Outra estratégia utilizada era a troca de experiências, que criava um clima de confiança entre pares e coordenadores. Os professores avaliavam, com freqüência, os encaminhamentos com vistas a avançar no processo formativo e aprimorar o desempenho pessoal e coletivo no trabalho com os alunos.

Depoimentos dos professores confirmam tais colocações:

"Quando começamos a desenvolver o projeto de intervenção pedagógica percebemos que tínhamos que partir para o estudo de caso dos alunos para entender melhor o porquê de tais comportamentos e atitudes, e mesmo para perceber melhor por onde poderíamos começar o trabalho. Essas informações são foram socializadas no coletivo e contribuíram muito na definição das estratégias de ensino." (Prof. Gildo, Matemática, $3^{\circ}$ ciclo, EMAM)

"Antes avaliávamos para dar notas. Aprovar ou reprovar. Agora, com o modelo formativo, avaliamos para saber o que o aluno aprendeu e o que precisa melhorar." (Prof ${ }^{a}$ Isaura, Matemática e Filosofia, $1^{\circ}$ ano, EMLF)

"Eu penso que a avaliação formativa traz um novo jeito da gente olhar o aluno. $O$ professor tem mais trabalho, mas os registros ajudam muito." (Prof ${ }^{a}$ Regina, Ciências e Educação Artística, $1^{\circ}$ ano, EMLF)

Este estudo, ainda identificou que a função do docente e os processos de sua formação e desenvolvimento profissional são 
considerados em relação aos diferentes modos de conceber a prática educativa. Essa prática fundamenta-se no pressuposto de que o ensino é uma atividade complexa que se desenvolve em cenários singulares, claramente determinados pelo contexto, com resultados, em grande parte, imprevisíveis e carregados de conflitos de valores que requerem opções éticas e políticas.

E o professor, diante dos desafios, orientará sua prática, prioritariamente, na aprendizagem da própria prática, para a prática e a partir da prática. Por meio da experiência, os docentes se formam e adquirem sabedoria que requer a intervenção criativa e adaptada às circunstâncias singulares da prática docente de avaliação.

$\mathrm{O}$ enfoque reflexivo da prática parte do reconhecimento da necessidade de se analisar o que realmente fazem os professores quando enfrentam problemas complexos na sala de aula. Daí as questões: o que fazem os professores para compreender os problemas e como utilizam o conhecimento científico e sua capacidade intelectual? Como enfrentam situações incertas e desconhecidas? Como elaboram e modificam rotinas, experimentam hipóteses de trabalho, utilizam técnicas, instrumentos e materiais conhecidos? E como recriam estratégias e renovam procedimentos de avaliação.

Essa habilidade ou conhecimento prático é analisado em profundidade por Schön como um processo de reflexão na ação ou como um diálogo reflexivo com a situação problemática concreta. Não se pode compreender a atividade eficaz do professor quando enfrenta os problemas singulares, complexos, incertos e conflitantes da aula se não se entendem esses processos de reflexão na ação. Aliás, Schön oferece uma contribuição importante para o estudo do saber dos professores. Segundo ele, os professores criam um conhecimento específico e ligado à ação, que só pode ser adquirido pelo contato com a prática. É um conhecimento pessoal, tácito e não sistemático, espontâneo, intuitivo, experimental, cotidiano.

Nessa perspectiva, Schön (1992) defende a reflexão dos professores na e sobre a sua prática. Ressalta a idéia de um practicum reflexivo, ou seja, um espaço de formação em que o professor tenha oportunidades de refletir constantemente sobre os problemas e a dinâmica postos pela sua atuação cotidiana. Ao propor uma epistemologia da prática, Schön (1992) apresenta conceitos inerentes à nova concepção de prática profissional, para a constituição do pensamento prático do professor: o conhecimento-na-ação, $a$ reflexão-na-ação e a reflexão-sobre-a-ação e sobre-a-reflexão-na-ação. 


\section{CONSIDERAÇÕES FINAIS}

A pesquisa realizada evidenciou que os docentes do $3^{\circ}$ ciclo produziam saberes por meio dos quais compreendiam e interpretavam sua prática. Esses saberes, em contrapartida, faziam com que eles se distanciassem dos saberes adquiridos fora dessa prática (Tardif, Lessard e Lahaye, 1991).

De fato, quando se interrogou o professor sobre seus saberes e sua relação com esses saberes, ele priorizou, a partir de categorias de seu discurso, os saberes denominados práticos ou da experiência. O que caracteriza, de um modo global, esses saberes práticos ou da experiência é o fato de se originarem da prática cotidiana da profissão e serem por ela validados.

Cotidianamente, os professores partilhavam, uns com os outros, seus saberes mediante as atividades que produziam, modos de fazer e de organizar a sala de aula, de preparar atividades de intervenção e de avaliação processual, etc. Trocavam informações sobre os alunos e dividiam um saber prático sobre sua atuação.

Quanto à questão referente à relação entre $o$ desafio da implementação da avaliação formativa e o desenvolvimento de um projeto de formação no cotidiano do trabalho escolar, a pesquisa evidenciou que as discussões realizadas pelos professores nos encontros de capacitação os ajudaram a refletir sobre a prática docente de avaliação formativa. Os professores das duas escolas tiveram oportunidade de rever concepções de currículo, docência e avaliação. Os docentes com mais tempo de magistério, em geral, não tiveram acesso às novas propostas pedagógicas. E mesmo os formados mais recentemente julgavam ter limites teórico-práticos no tratamento desses temas. Em diversos depoimentos relataram que estavam utilizando os espaços-tempos coletivos para aprender a lidar com o aluno do $3^{\circ}$ ciclo e promover o processo de ensino-aprendizagem.

Em seu PPP, os professores assumiram o desafio de implementar uma nova prática docente de avaliação formativa, proposta pela Escola Plural e legitimada pelo coletivo da escola. Nesse sentido, percebeu-se que o estudo, a assessoria e o acompanhamento dos professores em relação à avaliação foram substanciais para promover mudança significativa em sua postura: sentiram-se mais seguros e mobilizados no acompanhamento sistemático do aluno durante o processo; conseguiram elaborar alguns instrumentos, observar, coletar e registrar maiores informações sobre os alunos; passaram a fazer uma análise mais ampla do desenvolvimento do aluno não enfatizando tanto os resultados das provas, mas diversificando 
os instrumentos; puderam ter outras percepções sobre a sua prática pedagógica. Passaram a identificar e a retomar, também, os conteúdos em que os alunos evidenciavam necessidade de maior intervenção ou mesmo de mudança de estratégia didática.

Além disso, buscavam auxílio entre eles quando tinham dúvidas na elaboração dos instrumentos, os quais, gradativamente, melhoravam a qualidade do ensino. Alguns já questionavam a sua prática quando não obtinham um bom desempenho do aluno, fazendo sua auto-avaliação e propondo ao aluno que também avaliasse seu desempenho. A maioria dos professores demonstrou predisposição para continuar aperfeiçoando sua prática com a convicção de que, então, melhoraria o desempenho de seus alunos.

A prática de avaliação, construída pelos professores das duas escolas, indicou que o projeto de formação docente requer processo e realização no cotidiano do trabalho. Por conseguinte, ele será visível se houver desejo efetivo de participar dele, ou melhor dizendo, vontade política para efetuar mudanças, pois a formação continuada requer planejamento, acompanhamento qualificado de professores que atuem como interlocutores, podendo assessorar os docentes em suas buscas e desafios.

Destaca-se aí a necessidade de repensar a estratégia de promoção de cursos que polarizam alguns poucos professores em determinados locais, externos às escolas, substituindo-a por estratégias de formação nos espaçostempos pedagógicos. Desse modo, deve-se ampliar as oportunidades de participação dos professores, pois o contexto escolar demanda a formação no cotidiano do trabalho, porque esse é o tipo de formação que interessa ao conjunto dos professores e sobre o qual as escolas podem ter controle, para melhorar a qualidade do ensino. Nesses espaços-tempos pedagógicos, a adoção de um projeto de formação do tipo interativo-reflexivo inclui as propostas de formação cujos modelos se organizam em torno da resolução de problemas do cotidiano do professor, o que é feito com a ajuda mútua dos colegas e de assessores que atuam como interlocutores nas discussões.

Concluindo, práticas de formação que tomem como referência as dimensões coletivas contribuem para a emancipação profissional e para a consolidação de uma profissão que é autônoma na produção dos seus saberes e dos seus valores. A formação, como um processo dinâmico e com possibilidades de aperfeiçoamento crescente, pode ser entendida, também, como um processo contínuo. Nesse sentido, a prática profissional pode ser concebida como elemento constitutivo da formação continuada dos profissionais. 
Recuperam-se, nesse processo, três aspectos considerados essenciais à formação do professor, nos tempos atuais: a importância do espaço da escola e da cultura escolar como instâncias mediadoras das relações entre a escola e a sociedade; a importância dos saberes pedagógicos gerados no cotidiano das práticas escolares e as suas relações com os vários campos de conhecimentos que compõem as áreas de formação básica da educação de todo cidadão; o entendimento de que o professor é também, e sobretudo, um profissional reflexivo, que, cada vez mais, é desafiado a transformar as práticas docentes de avaliação garantindo às crianças e adolescentes o direito à educação e o sucesso escolar.

\section{REFERÊNCIAS BIBLIOGRÁFICAS}

AMARAL, Ana Lúcia. As políticas públicas de avaliação e sua repercussão nas práticas pedagógicas da Escola Plural. In: REUNIÃO ANUAL DA ASSOCIAÇÃO NACIONAL DE PÓS-GRADUAÇÃO E PESQUISA EM EDUCAÇÃO, 25. Anais. Caxambu, 2002.

BELO HORIZONTE. Prefeitura Municipal. Carta de Princípios da Rede Municipal de Educação de Belo Horizonte. Belo Horizonte: PBH; SMED, 2001.

CANDAU, V. M.; LELIS, I. A. A Relação teoria-prática na formação do educador. In: CANDAU, V. M. (org.). Rumo a uma nova didática. 3. ed. Petrópolis: Vozes, 1990. p.49-63.

CORRÊA, M. L.; SOUZA, K. O. Algumas práticas da formação continuada: entraves à implementação de mudanças político-pedagógicas? Presença Pedagógica, v.7, n.38, p.41-51, mar./abr. 2001.

DALBEN, Ângela I. M. L. F. Avaliação escolar: um processo de reflexão da prática docente e da formação do professor no trabalho. Belo Horizonte, 1998. Tese (dout.) Universidade Federal de Minas Gerais, Faculdade de Educação.

DEWEY, J. How we think. Boston: Heath, 1933.

ENGUITA, M. F. A Ambigüidade da docência: entre o profissionalismo e a proletarização. Teoria e Educação. Porto Alegre, n.4, p. 41-61, 1991. Dossiê: Interpretando o trabalho docente.

FREIRE, P.; FAUNDEZ, A. Por uma pedagogia da pergunta. Rio de Janeiro: Paz e Terra, 1985. 
GAUTHIER, C. et al. Por uma teoria da pedagogia: pesquisas contemporâneas sobre o saber docente. Trad. de Francisco Pereira de Lima. Ijuí: UNIJUÍ, 1998.

GOMES, Suzana dos Santos. Tessituras Docentes de Avaliação Formativa. Belo Horizonte, 2003. Dissertação (mestr.) Faculdade de Educação/UFMG. 213p.

KRAMER, S. Melhoria da qualidade do ensino: o desafio da formação de professores. Revista Brasileira de Estudos Pedagógicos, Brasília, n.165, p.189$207,1989$.

21, 1995.

Dando vez mestre. Presença Pedagógica, Belo Horizonte, n.4, p.5-

LÜDKE, M. Formação de professores e avaliação. Ensaio: Aval. Pol. Públ. Educ., Rio de Janeiro, v.3, n.8, p.331-336, jul./set.1995.

. Sobre a socialização profissional dos professores. Cadernos de Pesquisa, São Paulo, n. 99, p. 5-15, nov. 1996.

Socialização profissional de professores: as instituições formadoras. Rio de Janeiro: PUC-RJ, 1998. (Relatório de pesquisa)

MAGALHÃES, C. R.; TANCREDI, R. M. S. P. Como são vistos e ensinados na escola os alunos que fracassam: repercussões para a construção de uma prática voltada para o sucesso escolar. In: MIZUKAMI, M. da G.; REALI, A. M. de M. R. Formação de professores, práticas pedagógicas e escola. São Carlos: Ed. UFSCar, 2002. cap. 1, p. 29-49.

MARTINS, Pura Lúcia O. A Didática e as contradições da prática. Campinas: Papirus, 1998.

MEDIANO, Z. D. A Formação em serviço do professor a partir da pesquisa e da prática pedagógica. Tecnologia Educacional, Rio de Janeiro, n.105/106, p.31-36, 1992.

MENDONÇA, Ana W. P. C. A Escola como espaço de formação continuada do professor. Revista de Educação da AEC, Brasília, n.79, p. 39-42, 1991.

MIZUKAMI, M. da G.; REALI, A. M. de M. R. (orgs.) Formação de professores, práticas pedagógicas e escola. São Carlos: Ed. UFSCar, 2002.

NÓVOA, A. (org.) Vidas de professores. Porto: Porto Editora, 1992. 
NÓVOA, A. Formação de professores e profissão docente. In: NÓVOA, A. (org.). Os Professores e sua formação. Lisboa: Publicações Dom Quixote, 1995, p.13-33.

PÉREZ-GÓMEZ, A. I. O pensamento prático do professor: a formação do professor como profissional reflexivo. In: NÓVOA, A. (org.). Os Professores e sua formação. Lisboa: Dom Quixote, 1995.

POPKEWITZ, T. S. Profissionalização e formação de professores: algumas notas sobre a sua história, ideologia e potencial. In: NÓVOA, A. (org.). Os Professores e sua formação. Lisboa: Dom Quixote, 1995.

RAYMOND, D. Éclatement des savoirs et savoirs en rupture: une réplique à Van der Maren. Revue des Sciences de l'Éducation, v.19, n.4, p.187-200, 1993.

SCHÖN, D. A. Formar professores como profissionais reflexivos. In: NÓVOA, A. (org.) Os Professores e sua formação. Lisboa: Dom Quixote, 1992. p. 77-92.

- Utilizando o ensino prático reflexivo para desenvolver habilidades profissionais. In: SCHÖN, D. A. Educando o profissional reflexivo: um novo design para o ensino e a aprendizagem. Porto Alegre: Artes Médicas Sul, 2000.

TARDIF, M. Saberes docentes e formação profissional. Petrópolis: Vozes, 2002.

TARDIF, M.; LESSARD, C.; LAHAYE, L. Os Professores face ao saber: esboço de uma problemática do saber docente. Teoria e Educação, Porto Alegre, n. 4, 1991.

ZEICHNER, K. Traditions of reform in U. S. teacher education. Journal of Teacher Education, 1990.

EDUCA, 1993.

A Formação reflexiva de professores: idéias e práticas. Lisboa:

Entrevista - Formação de professores: contato direto com a escola. Presença Pedagógica, v.6, n.34, p. 5-15, jul./ago. 2000.

Recebido em: março 2005

Aprovado para publicação em: julho 2005 